\title{
Development of Peureulak History in Video Based for Learning Social Science in Grade IV Students of 1 Peureulak East Aceh
}

\author{
Rosnida $^{1}$, Ichwan Azhari ${ }^{2}$, Wildansyah Lubis ${ }^{3}$ \\ ${ }^{1}$ State University of Medan (UNIMED), Medan, Indonesia \\ ${ }^{2}$ State University of Medan (UNIMED), Medan, Indonesia \\ ${ }^{3}$ State University of Medan (UNIMED), Medan, Indonesia \\ * The corresponding outhor: rosnidayahya@gmail.com
}

\begin{abstract}
Peureulak's history video in social studies learning for grade 4 students at SDN 1 Peureulak, East Aceh. This type of research is research and development which refers to the development model of Borg And Gall. The results of this study indicate that: (1) Validation of material experts on the content feasibility assessment is on very good criteria (96.25\%), language feasibility is in very good criteria (89\%) and the feasibility of presentation is in sufficient criteria (74\%). The practicality level of Peureulak's historical videos is concluded based on teacher responses and student responses; (i) Students' responses to Peureulak's historical video in the field trial amounting to $83 \%$ of students stated that the Peureulak history video was practical, (ii) The response of Peureulak's history video teacher in the field trial was $81 \%$ in the practical category. Likewise with the influence of the use of Peureulak's historical videos on student learning outcomes based on the pretest and posttest analyzed using $N$-Gain obtained an average gain value of 0.8 where in the high category.
\end{abstract}

Keywords : video, Peureulak, IPS, Learning Outcomes

\section{Introduction}

Education plays an important role in improving the quality of human resources that support the progress of the nation and state. Social studies education as a field of study given at the level of education in the school environment, not only provides knowledge, but also provides provision of values and attitudes and skills in the lives of students in the community, nation, and country in various characteristics (Prayitno et al. 2010: 700).

In general, schools still consider social studies to simply transfer knowledge from educators to students, regardless of the purpose of the subject. So that the existing learning process is not able to encourage students to actively develop the potential that exists in him. Educators deliver subject matter through lectures in the hope that students can understand and respond according to the material presented.

The progress of Science and Technology (IPTEK) which has influenced various aspects of human life has also influenced the paradigm of the world of education. Education is currently growing; various kinds of efforts are made in the renewal process, in order to improve the quality and quantity of education. To improve the quality of education various breakthroughs are needed, both in curriculum development, learning innovation, and fulfillment of educational facilities and infrastructure. Teachers are required to make learning more innovative which encourages students to learn optimally both in independent learning and in classroom learning. The development of learning media is one way to increase student interest in social studies. An educator is demanded creativity to make learning media interesting, innovative, varied and in accordance with the level of student needs. This fact is in accordance with the results of field observations that researchers in Peureulak 1 Public Elementary School still use available teaching materials that are not in accordance with the 
curriculum, conventional methods and teachers also do not use other supporting learning media, such as using media tutorial video.

On the other hand, Social Studies learning outcomes of students at SD Negeri 1 Peureulak are still in the low category, not yet achieving the graduation target of learning outcomes set for lessons. This condition is a concern; teachers need creativity to better guide and direct students to be able to improve their learning outcomes. In an effort to improve learning outcomes, innovation is needed in making these learning media. Therefore learning media need to have a form of presentation that is light and attractive to students.

Therefore, the researcher feels that it is necessary to develop learning media that are suitable for use in order to teach local history lessons in IPS grade IV elementary schools in the local environment (Peureulak) that are creative, practical, and relevant to the learning that will be held. This is intended to provide social studies teaching in a more interesting form for students so that learning is expected to be more interesting and more meaningful. Besides that, it can improve the quality of the learning process and be able to achieve the learning objectives that have been formulated and will also make students more familiar with and appreciate the historical heritage that is close to their environment.

\section{Literature Review}

\subsection{Social Education}

Social Sciences (IPS) is often identified with the terms Social Education, Citizenship Education and Social Science Education. Somantri (2000: 3) suggests that Social Studies Education is described as "Educational programs that choose educational materials from disciplines of social sciences and humanities that are organized and presented scientifically and psychologically for educational purposes. The National Council For Social Studies (NCSS) stated that Social Studies is an integrated study of social science and humanities to promote civic competence. Within the school program, social studies provide coordinated, systematic study drawings such as anthropology, archeology, economics, geography, history, law, philosophy, political science, psychology, region and sociology, as well as appropriate content from the humanities, mathematics, and natural sciences. "The primary purpose of social studies is to help young people to be informed and reasoned for interdependent world democratic society" (Elli. 1998: 2).

While Barth (1990: 360) stated that "Social Studies assigned the mission of citizenship education, that the study of personal / social problems in the integrated school curriculum interdisciplinary would emphasize the practice of decision making".

Based on the above understanding, it can be concluded that IPS is an integrated study of the social sciences and humanities to improve civic competence.

\subsection{Learning and Learning Outcomes}

Psychologists and teachers generally view learning as a changing behavior, this view separates the explicit understanding between the understanding of the learning process and activities that are merely rote (Sagala, 2013: 11-12). Owhittaker states that learning is a process where behavior (in a broad sense is generated or changed through practice or practice (Mardianto. 2013: 45)

Meanwhile, learning outcomes are the results achieved from the teaching and learning process in accordance with educational goals. Learning outcomes are measured to determine 
the achievement of educational goals so that learning outcomes must be in accordance with educational goals (Purwanto. 2011: 53-54).

Kingsley divides three kinds of learning outcomes: (1). Skills and habits, (2). Knowledge and understanding, (3). Attitudes and ideals. Each type of learning outcome can be filled with items that have been set in the curriculum (Sudjana. 2010: 22). Bloom et al. classify the learning outcomes into three parts, namely cognitive, affective and psychomotor (Kurniawan. 2014: 10). Meanwhile, Gagne divides learning outcomes into five, namely: (1). Intellectual skill (2). Cognitive strategy (3). Verbal information (4). Motoric skill (5). Attitude (Richey. 2000: 92-94).

Peureulak's history. Peureulak is the oldest country in Sumatra, whose name remains unchanged throughout the century. And it was well known among the previous travelers, along with the world warriors who operated in Malacca such as the Chinese, Arabs, Persians, Hindustans, Hindus, Italians, Portuguese and others.

Abu Ishk Al Makarani pasy noted that in the year $173 \mathrm{H}(800 \mathrm{M})$ anchored in Bandar Peureulak a merchant ship from the bay of kambey (Gujarat) under the leadership of the Nakhoda Khalifah with a number of Muslim traders; and then they settled in Peureulak to run Da'wah Islamiyah. After nearly 50 years of jihad in the field of da'wah, it could only be established in Peureulak, an Islamic empire with the first king, with the title Sultan Alaiddin Saiyid Maulana Abdul Aziz Shah, who ruled in 225-249 H (Hasjmy. 1987: 7)

In a period of approximately half a century, in the kingdom of Peureulak an Islamic community with members consisting of native descendants, mixed descendants, namely peranakan Arabs, Persians, and Gujarati was established, so that on Tuesday, 1 Muharram $225 \mathrm{H}(840 \mathrm{M})$ proclaimed the establishment of the Peureulak Islamic Empire, with the appointment of its first Sultan Saiyid Maulana Abdul Aziz (descendant of Quraysh) with the title Sultan Alaiddin Saiyid Maulana Abdul Aziz Syah, and the capital city of Bandar Peureulak changed to "Bandar Khalifah", as a memento to the Caliph.

Pedigree of the kings of the Islamic Empire of Peureulak:

1. Sultan Alaiddin Saiyid Maulana Abdul Aziz Shah, 225-249 H (840-864 AD)

2. Sultan Alaiddin Saiyid Maulana Abdurrahman Syah, 249- 285 H (864-888 AD)

3. Sultan Alaiddin Saiyid Maulana Abbas Syah, 285-300 H (888-913 M)

4. Sultan Alaiddin Saiyid Maulana Ali Mughaiyat Shah, 302-305 H (915-918 AD)

5. Sultan Makhdum Alaiddin Malik Abdulkadir Syah, Johan Berdaulat, 306-310 H (918-922 M)

In 375 AH (986 AD), the Srivijaya army attacked Peureulak, who was later repelled. Sultan Makhdum Alaiddin Malik Muhhamad Amin Shah II Johan Berdaulat (622-662 AH), married his daughter Ratna Kemala with the King of Malacca, Sultan Muhammad Syah who held the title Peramesjwara Iskandar Syah, while his second daughter Putri Ganggang was married to the king of Pase, Meurah Silu or Malikus Saleh are both political marriages.

\section{Research Methods}

This type of research is research and development with Borg and Gall teaching material development model whose procedure has 10 steps or stages. In this study researchers only used 7 steps. This research was conducted at SD Negeri 1 Peureulak. Following the 
development of the research conducted by researchers based on the development model of Borg and Gall.

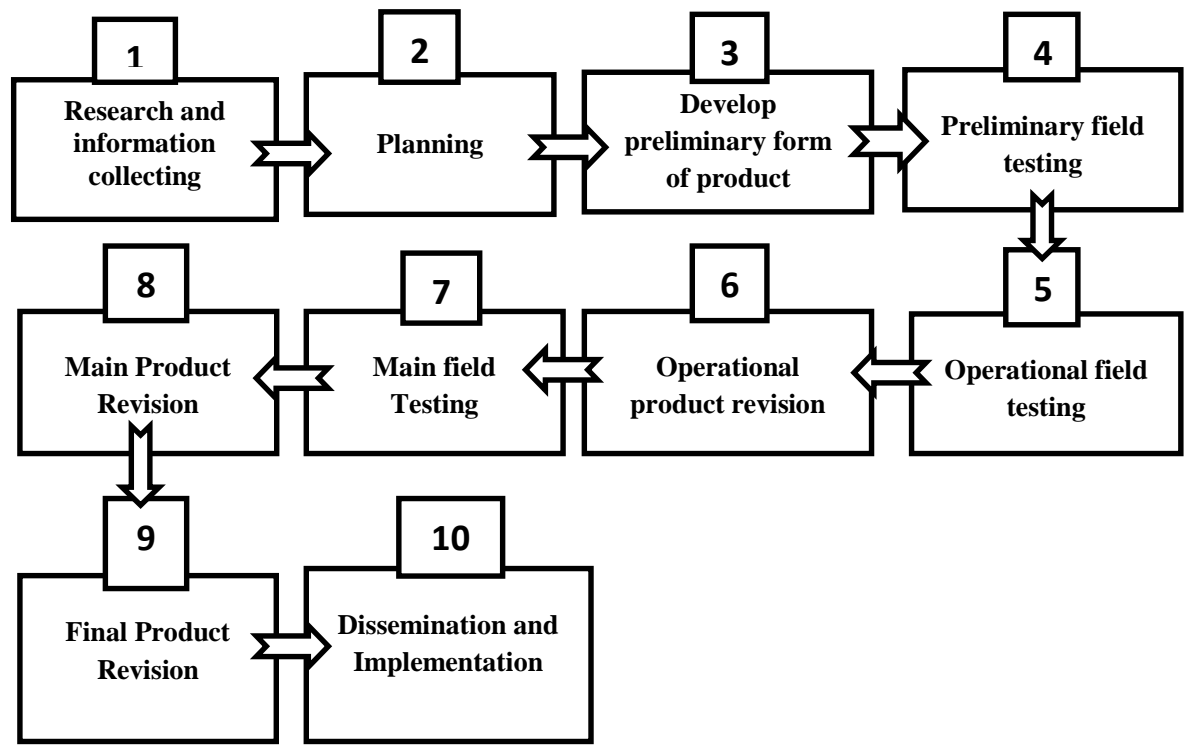

Figure 3.1 Design Flow of Research and Development

The data obtained in this study are divided into two, namely: qualitative data and quantitative data. Qualitative data is obtained through validation sheets and quantitative data obtained from the series and tests of student learning outcomes. Questions used in the form of multiple choices that aim to improve student learning outcomes. The indicators used are based on minimum completeness criteria (KKM).Qualitative data obtained through validation sheets and questionnaires (teacher and student responses) using linkert scale. The scores obtained are then inputted into the validity video category table adapted by the researcher (Sugiyono, 2015).

Table 1. Validity and Video Categories

\begin{tabular}{|c|l|l|}
\hline No & Interval Persentase & Kriteria \\
\hline 1 & $81 \% \leq \mathrm{X}<100 \%$ & Very Good \\
\hline 2 & $61 \% \leq \mathrm{X}<80 \%$ & Good \\
\hline 3 & $41 \% \mathrm{X}<60 \%$ & Average \\
\hline 4 & $21 \% \mathrm{X}<40 \%$ & Above Average \\
\hline 5 & $0 \% \mathrm{X}<20 \%$ & Errors \\
\hline
\end{tabular}

Peureulak's historical video is categorized as valid if the product developed has good criteria. If the product is developed under good criteria, the researcher will revise the product developed. Products are categorized as effective if the learning outcomes obtained by students reach a percentage of $85 \%$ on classical learning completeness criteria through pretest and posttest. 


\section{Results And Discussion}

This research is research and development (research and development) to produce a product in the form of Peurelak's history video in social studies learning for 4th grade students of SDN 1 Peureulak, East Aceh.This development research refers to the development model of Borg \& Gall, which is limited to just a few stages. These stages include: a) Information collection stage; b) Planning stage; c) Product development stage; and d) Phase validation and testing. The following is an explanation of each stage carried out in this research and development:

\subsection{Research and Information Collecting}

This stage begins with a literature study related to the problems studied and formulation for the research framework. At this stage the researcher found a curriculum mismatch with available teaching materials. The curriculum requires the teacher so that students are more aware of the local history where students live. This is so that students can get to know and love history in their residence in one district / city.After the available teaching materials are analyzed, there is no subject matter of local history where students live as demands in the curriculum. In the teaching material the presentation of the subject matter more explains the history outside Aceh (material is too broad) for students to study because for their own local history students lack mastery.

The teacher needs analysis aims to find out how much the teacher needs for learning media in the form of Peureulak's historical videos. Based on the results of the questionnaire analysis the teacher's needs can be concluded that the teacher has knowledge of the importance of Peureulak's historical videos in the implementation of teaching and learning especially can help improve student learning outcomes. The results of the teacher's answers above can be seen that $75 \%$ of teachers stated that they were very familiar with historical video media but $100 \%$ of teachers never made Peureulak's historical video media. $75 \%$ of teachers know the steps to compile Peureulak's historical videos. However, only $50 \%$ of teachers know how to develop Peureulak's historical video media so that $75 \%$ of teachers need Peureulak's historical videos that are valid, effective and practical.

Student analysis is a review of the characteristics of students at the research location. When viewed from the socio-economic background obtained through interviews with teachers, the work of the parents of these students includes a variety, including Civil Servants (PNS), traders, laborers and others. But overall the parents' socio-economic background is in the middle and lower middle categories. Because, only a few students have parents who work as civil servants. This condition certainly affects student learning because most of their parents are busy working to meet their daily needs and do not have enough time to accompany their children at home. Evident from homework (PR) given by the teacher, there are a number of students who have not finished doing it with reasons not to understand and no one accompanying when studying at home.

\subsection{Planning}

At this stage the researcher conducts a standard review of the contents. The review of content standards is done by making a mapping of Core Competencies (KI) and basic competencies (KD), Core Competencies and Basic Competencies chosen in the development of this product are: 


\begin{tabular}{|l|l|}
\hline Basic Competence & Objective of Study \\
\hline $\begin{array}{l}\text { Appreciate various } \\
\text { historical heritage in the } \\
\text { local environment } \\
\text { (district / city, province) }\end{array}$ & $\begin{array}{l}\text { 1. Mention historical inheritance according to the } \\
\text { century (because it spreads) in the local environment } \\
\text { local environment }\end{array}$ \\
& $\begin{array}{l}\text { 3. Gather information about the origin of the name of a } \\
\text { place from various sources }\end{array}$ \\
4. Get to know historical heritage in the local \\
environment
\end{tabular}

The second phase also consists of making research instrument grids which become Peureulak's historical video assessment criteria. The instrument grid that has been completed and then developed into a research instrument. The research instruments that will be used are validation sheets, teacher and student questionnaires and multiple choice tests. The validation sheet is used to determine the validity of Peureulak's historical videos based on the assessment of material experts, media construction experts and linguists.

\subsection{Product Validation}

Validation is an important part in developing historical videos to correct errors and weaknesses from the design results (draft I). Validation is done by submitting a history video to the validator along with the validation sheet to be further examined and assessed by the validator's level of feasibility. The results of expert evaluations of Peureulak's history videos for grade IV elementary schools were submitted through the questionnaire method as follows:

Tabel 2. Expert Evaluations of Peureulak's History Videos

\begin{tabular}{|c|l|c|c|c|}
\hline \multirow{2}{*}{ No } & \multirow{2}{*}{ Aspect } & \multicolumn{2}{|c|}{ Meeting } & \multirow{2}{*}{ Process } \\
\cline { 3 - 4 } & & I & II & \\
\hline 1 & Materi & $84 \%$ & $96,25 \%$ & $12,25 \%$ \\
\hline 2 & Konstruksi & $79 \%$ & $89 \%$ & $10 \%$ \\
\hline 3 & Bahasa & $60 \%$ & $74 \%$ & $14 \%$ \\
\hline
\end{tabular}

Based on the results of the validation, the expert stated that Peureulak's history video is suitable to be used in the field.

\subsection{Preliminary Field Testing.}

By involving 9 students in class VI-C. The limited-scale field testing stage was carried out using student response questionnaires where to obtain quantitative data. Based on the results of the analysis, the average percentage of the results of the evaluation on limited group trials on Peureulak's historical videos was $83.56 \%$ including the excellent category. Based on the results of the assessment even though in the excellent category there are several things evaluated, namely the time given to students to understand the material to be extended. And additional explanations by the teacher need to be done to deepen student knowledge. 


\subsection{Revision of Main Products}

At these stage researchers make improvements from the revised results which can be done at the stage of limited field testing will be carried out repairs on the main group trials, while some aspects that will be improved include students need more time to understand the historical heritage around them.

Main Field Testing

The results of the trial data in the field test stage were analyzed to determine how much the improvement in learning outcomes was developed based on the pretests and posttest conducted. The pretest and posttest was conducted in class IV of SD Negeri 1 Peureulak.

Tabel 3. Recapitulation of the Value of Student Mastery

\begin{tabular}{|c|c|c|}
\hline \multirow{2}{*}{ Activity } & \multicolumn{2}{|c|}{ Average Score of Students } \\
\cline { 2 - 3 } & IV-A & IV-B \\
\hline Pretest & $42 \%$ & $53 \%$ \\
\hline Postest & $87 \%$ & $83 \%$ \\
\hline Process & $45 \%$ & $30 \%$ \\
\hline
\end{tabular}

Based on the table above there has been an increase in student learning outcomes from pretest and posttest by $45 \%$ with teacher responses of $81 \%$ and student responses by $83 \%$ with a gain score of 0.8 in the high category. Thus it can be concluded that learning using Peureulak's history videos can improve learning outcomes of fourth grade students at SDN 1 Peureulak.

\section{Conclusion}

1. The level of feasibility of Peureulak's historical videos based on the results of the material and language expert validation on the feasibility of the contents of Peureulak's developed history is included in the "Very Good" category. Based on the expert of learning media construction on the history of Peureulak which was developed in the "sufficient" category too.

2. The results of the practitioner from the teacher state that the teacher needs Peureulak's historical video in the learning process while students prefer learning and make it easier for students to learn to use Peureulak's historical videos.

3. The effect of using Peureulak's historical videos on student learning outcomes is higher compared to using teaching materials that are used daily where the students' pretest scores are $42 \%$ and in the posttest increases to $87 \%$. So that it can be stated that learning using Peureulak's history videos can improve learning outcomes of fourth grade students at SDN 1 Peureulak.

\section{References}

Ellis, Arthur K. 1997. Teaching and Learning Elementary Social Studies, Sixth Edition. USA: Seattle Pacific University.

Barth, J.L. 1990. Method of Instruction in Social Studies Education. New York: University Press of America.

Hasjmy. A. 1990. Sejarah Kebudayaan Islam di Indonesia. Jakarta: Bulan Bintang.

Kurniawan, Deni. 2014. Pembelajaran Terpadu Tematik. Bandung: Alfabeta.

Mardianto. 2013. Psikologi Pendidikan. Medan: Perdana Publishing. 
Prayitno, Dkk. 2010. Pendidikan Karakter Dalam Pembangunan Bangsa. Sumatera Utara : Pasca Sarjana Universitas Negeri Medan

Purwanto, N. 2011. Prinsip-Prinsip Dan Teknik Evaluasi Pembelajaran. Bandung: Remaja Rosdakarya.

Richey, Rita C. 2000. The Legacy Of Robert M Gagne. New York: Wayne State University.

Sagala, Saiful. 2013. Konsep dan Makna Pembelajaran. Bandung: Alfabeta.

Somantri, Numan. 2000. Menggagas Pembaharuan Pendidikan IPS. Bandung: Remaja Rosdakarya

Sugiyono. 2010. Metode Penelitian Kuantitatif, Kualitatif and $R \& D$. Bandung: Alfabeta. 